University of Nebraska - Lincoln

DigitalCommons@University of Nebraska - Lincoln

$12-1963$

\title{
The Analysis of Micro Amounts of Binapacryl, EPN, Methyl Parathion, and Parathion
}

Donald A. George

USDA-ARS

Follow this and additional works at: https://digitalcommons.unl.edu/usdaarsfacpub

George, Donald A., "The Analysis of Micro Amounts of Binapacryl, EPN, Methyl Parathion, and Parathion" (1963). Publications from USDA-ARS / UNL Faculty. 1653.

https://digitalcommons.unl.edu/usdaarsfacpub/1653

This Article is brought to you for free and open access by the U.S. Department of Agriculture: Agricultural Research Service, Lincoln, Nebraska at DigitalCommons@University of Nebraska - Lincoln. It has been accepted for inclusion in Publications from USDA-ARS / UNL Faculty by an authorized administrator of DigitalCommons@University of Nebraska - Lincoln. 
George, Donald A.

\section{4}

THE ANALYSIS OF MICRO AMOUNTS OF BINAPACRYL, EPN, METHYL PARATHION, AND PARATHION

Journal of the A.0.A.U. (Vol. 46, No. 6, 1963) 


\section{The Analysis of Micro Amounts of Binapacryl, EPN, Methyl Parathion, and Parathion}

By DONALD A. GEORGE (Entomology Research Division, Agricultural Research Service, U.S. Department of Agriculture, Yakima, Wash.)

Aromatic nitrated insecticides can be determined by a microchemical method based on the Averell-Norris procedure. The method is more sensitive than other known methods, and interference from plant extracts is low.

Aromatic nitrated insecticides have been analyzed by various methods. The method of Averell and Norris (1) for the determination of parathion is one of the most widely used. Kolbezen and Barkley (2) determined Chlorthion (O-(3-chloro-4-nitrophenyl) O,O-dimethyl phosphorothioate) in a manner analogous to the Averell-Norris parathion method. Young (3) increased the sensitivity of this method for determining 1-chloro-2-nitrobenzene in pineapple. Rosenthal, et al. (4) determined dinitrooctylphenol by a distillation process in the analysis of residues of Karathane, a mixture of dinitro(1-methylheptyl)phenyl crotonate $(78 \%)$ and dinitro(1-methylheptyl)phenol and related compounds $(22 \%)$. EPN, methyl parathion, $p$-nitrophenol, and paraoxon residues have been determined by use of the Averell-Norris procedure. Binapa- cryl (2-sec-butyl-4,6-dinitrophenyl-3-methyl2-butenoate) is determined by the method of Niagara Chemical Division of Food Machinery Corp. (5).

The microcolorimetric method presented utilizes the reactions of the Averell-Norris procedure and has definite advantages over the methods cited above. The method has a sensitivity of approximately ten-fold over other methods and there is a low degree of interference from plant extracts. The plant material is extracted with $n$-hexane:isopropyl alcohol, which does not extract a large amount of interfering substances from the sample, and during the subsequent reduction and filtration steps the plant interferences are largely removed.

The method consists of reducing the nitro grouping, diazotizing, and then coupling with $N$-1-naphthylethylenediamine dihydrochloride, and concentrating the resultant color by extracting into chloroform. This method has also been applied to determination of Guthion (O,O-dimethyl-S-(4-oxo-1,2, 3-benzotriazin-3 $4 H$ )-ylmethyl) phosphorodithioate), a nitrogen ring compound (6), by first hydrolyzing to break the ring, then 
reducing, diazotizing, coupling, and extracting into chloroform.

Analysis of Guthion standard solutions by this method gave absorbance readings of nearly twice those obtained by the method of Meagher, et al. (7).

\section{METHOD}

\section{Reagents}

(a) Binapacryl standard solution.-(Niagara Chemical Division, Food Machinery Corp.). One ml contains $10 \mu \mathrm{g}$ in redistilled $n$-hexane.

(b) Parathion and methyl parathion standard solutions. - (American Cyanamid Co.). One ml contains $10 \mu \mathrm{g}$ of redistilled $n$-hexane.

(c) EPN standard solution.-(E. I. duPont de Nemours \& Co.). One $\mathrm{ml}$ contains $10 \mu \mathrm{g}$ in redistilled $n$-hexane.

(d) Cotton. - Acetone-extracted and ovendried.

(e) n-Hexane.-Redistilled (over metallic sodium).

(f) Skellysolve B.-Any $n$-hexane with a low reagent blank can be used.

(g) Acid-alcohol solution.-Combine 2 parts 95\% ethyl alcohol and 2 parts concentrated $\mathrm{HCl}$, mix, and cool. Make fresh daily.

(h) Lanolin solution.-1\% in chloroform.

(i) Zinc powder. - Reagent grade, 80-200 mesh.

(j) Sodium nitrite $-0.25 \%$ in distilled water. Make fresh weekly and keep refrigerated.

(k) Ammonium sulfamate - $-2.5 \%$ in distilled water. Make fresh weekly and keep refrigerated.

(1) Dye solution. - 1\% N-1-naphthylethylenediamine dihydrochloride in distilled water. Add $0.5 \mathrm{~g}$ decolorizing carbon, mix, and filter through two fluted papers. Store in dark bottle under refrigeration and make fresh every other day.

\section{Determination}

Pipet aliquots of the standard insecticide solution containing 0-50 $\mu \mathrm{g}$ into $125 \mathrm{ml}$ Erlenmeyer flasks. Add $0.5 \mathrm{ml}$ lanolin solution, and evaporate the samples to dryness in a $40^{\circ} \mathrm{C}$ water bath, using a small stream of filtered air to speed evaporation. Add $5 \mathrm{ml}$ of the alcoholacid solution plus $0.8 \mathrm{~g}$ zinc, insert a small funnel into the opening of the flask, and reflux gently on a hot plate 10 minutes. Remove, filter through a small cotton plug into glass-stoppered test tubes, and wash with 20 $\mathrm{ml} 50 \%$ ethyl alcohol. Add $1 \mathrm{ml} 6 \mathrm{~N} \mathrm{HCl}$, mix, and let stand until samples come to room temperature. Add $1 \mathrm{ml}$ sodium nitrite solution, mix well, and let stand 10 minutes in the dark. Add $1 \mathrm{ml}$ ammonium sulfamate solution, mix well, and let stand 10 minutes in the dark. Add $2 \mathrm{ml}$ dye solution, mix, and let stand 20 minutes in dark, mixing at intervals. Add $4 \mathrm{ml}$ chloroform, shake, pipet off chloroform, and filter it through a small plug of cotton. Determine absorbance at $565 \mathrm{~m} \mu$, using chloroform as a reference. The color is stable for at least 1 hour.

\section{Experimental and Results}

The standard curves obtained by this method for $0-50 \mu \mathrm{g}$ of the nitrated pesticides follow Beer's Law. The ranges of absorbance readings of the standards and the maximum wavelengths, determined with a Beckman Model DB recording spectrophotometer, are reported in Table 1.

The extraction and cleanup procedures applicable to the nitrated insecticides can be used for this method. Van Middelem, et al. (8) have reported on the extraction and cleanup of parathion residues on leafy vegetables. The suggested cleanup procedure given in the Official Methods of Analysis of the AOAC (9) is also useful.

Known amounts of insecticides were added to apple and pear fruits and to apple and pear leaf tissue prior to extraction. The apple and pear fruits were extracted by tumbling, for a 5 minute period, with a $2: 1$ mixture of distilled $n$-hexane:isopropyl alco-

Table 1. Characteristics of the color produced from some nitrated aromatic insecticides

\begin{tabular}{l|c|c|c|c}
\hline \multicolumn{1}{c|}{ Insecticide } & Range in $\mu \mathrm{g}$ & $\begin{array}{c}\text { K Factor of } \\
\text { Color Produced }\end{array}$ & Range in Absorbance ${ }^{a}$ & $\begin{array}{c}\text { Maximum } \\
\text { Absorbance }^{a}, \mathrm{~m} \mu\end{array}$ \\
\cline { 2 - 3 } Binapacryl & $0-100$ & 0.0142 & $0.010-1.425$ & 565 \\
EPN & $0-50$ & 0.0318 & $0.012-1.600$ & 565 \\
Methyl parathion & $0-50$ & 0.0173 & $0.008-0.871$ & 560 \\
Parathion & $0-50$ & 0.0263 & $0.008-1.325$ & 560 \\
\hline
\end{tabular}

${ }^{a}$ Determined by Beckman Model DB recording spectrophotometer. 
Table 2. Average recovery of EPN, binapacryl, parathion, and methyl parathion added to apple and pear fruits, tomatoes, leaf lettuce, and apple and pear leaves

\begin{tabular}{|c|c|c|c|}
\hline Sample & Insecticide & Added, ppm & Recovery, \% \\
\hline \multirow[t]{4}{*}{ Apple fruits ${ }^{a}$} & $\mathrm{EPN}$ & $\begin{array}{c}0 \\
0.09 \\
0.50\end{array}$ & $\begin{array}{c}0 \\
85.4 \\
106.0\end{array}$ \\
\hline & Binapacryl & $\begin{array}{c}0 \\
0.10 \\
0.50 \\
0^{b} \\
0.47^{b}\end{array}$ & $\begin{array}{c}0 \\
68.7 \\
90.3 \\
0 \\
97.6\end{array}$ \\
\hline & Parathion & $\begin{array}{c}0 \\
0.09 \\
0.50\end{array}$ & $\begin{array}{c}0 \\
113.0 \\
58.3\end{array}$ \\
\hline & Methyl parathion & $\begin{array}{c}0 \\
0.09 \\
0.50\end{array}$ & $\begin{array}{c}0 \\
120.0 \\
73.3\end{array}$ \\
\hline Pear fruits ${ }^{c}$ & Binapacryl & $\begin{array}{c}0 \\
0.45\end{array}$ & $\begin{array}{c}0 \\
92.0\end{array}$ \\
\hline \multirow[t]{4}{*}{ Tomatoes } & $\mathrm{EPN}$ & $\begin{array}{c}0 \\
0.05 \\
0.25\end{array}$ & $\begin{array}{c}0 \\
72.0 \\
80.0\end{array}$ \\
\hline & Binapacryl & $\begin{array}{c}0 \\
0.05 \\
0.25\end{array}$ & $\begin{array}{c}0 \\
106.0 \\
80.0\end{array}$ \\
\hline & Parathion & $\begin{array}{c}0 \\
0.05 \\
0.25\end{array}$ & $\begin{array}{c}0 \\
109.0 \\
88.0\end{array}$ \\
\hline & Methyl parathion & $\begin{array}{c}0 \\
0.10 \\
0.25\end{array}$ & $\begin{array}{c}0 \\
86.5 \\
72.0\end{array}$ \\
\hline \multirow[t]{4}{*}{ Leaf lettuce } & $\mathrm{EPN}$ & $\begin{array}{c}0 \\
0.05 \\
0.25\end{array}$ & $\begin{array}{l}0.02 \\
80.0 \\
84.0\end{array}$ \\
\hline & Binapacryl & $\begin{array}{c}0 \\
0.05 \\
0.25\end{array}$ & $\begin{array}{c}0 \\
113.0 \\
100.0\end{array}$ \\
\hline & Parathion & $\begin{array}{c}0 \\
0.05 \\
0.25\end{array}$ & $\begin{array}{c}0 \\
96.0 \\
104.0\end{array}$ \\
\hline & Methyl parathion & $\begin{array}{c}0 \\
0.10 \\
0.25\end{array}$ & $\begin{array}{c}0 \\
58.5 \\
96.0\end{array}$ \\
\hline Apple leaves & Binapacryl & $\begin{array}{c}0 \\
0.05^{d} \\
0.50^{d} \\
5.00^{d}\end{array}$ & $\begin{array}{c}0 \\
99.0 \\
87.5 \\
90.5\end{array}$ \\
\hline Pear leaves & Binapacryl & $\begin{array}{c}0 \\
0.05^{d} \\
0.50^{d} \\
5.00^{d}\end{array}$ & $\begin{array}{c}0 \\
96.0 \\
94.0 \\
95.0\end{array}$ \\
\hline
\end{tabular}


hol. Three $\mathrm{ml}$ of the mixed solvent was added per gram of sample. The apple and pear leaf tissue samples were extracted by shaking with distilled $n$-hexane, in a small flask, for 1 minute.

Tomato and leaf lettuce samples were ground to a fine state of subdivision, frozen, and allowed to thaw slightly. Known amounts of insecticide were added to different samples and the fortified samples tumbled for 30 minutes with a 2:1 mixture of distilled $n$-hexane:isopropyl alcohol. Three $\mathrm{ml}$ of mixed solvent was added per gram of sample.

When a mixed solvent was used, the isopropyl alcohol was removed from the extract by repeated washing with distilled water. All extracts were finally dried by filtration through anhydrous sodium sulfate.

The extracts of apple and pear fruits and of apple and pear leaf tissues did not require any cleanup procedure before analysis.

The extracts of tomato and leaf lettuce did require this cleanup, however. An aliquot of the tomato and leaf lettuce extract was evaporated to approximately $25 \mathrm{ml}$ and shaken for 3 minutes with $1.5 \mathrm{~g}$ of a $2: 1$ mixture of Attaclay:Nuchar 190-N. The sample was filtered through a plug of acetone-washed cotton and overlaid with sodium sulfate, and the flask and filter were washed 4 times with $15 \mathrm{ml}$ portions of distilled benzene.

The extracts, both cleaned up and not cleaned up, were carefully evaporated to dryness, and the insecticide content was determined in the same manner as the standard curve.

The recovery of EPN, binapacryl, parathion, and methyl parathion added to apple and pear fruits, tomatoes, leaf lettuce, and apple and pear leaf tissue are presented in Table 2.

\section{Discussion}

To check possible interferences, a number of insecticides were analyzed by this method. When $100 \mu \mathrm{g}$ of Guthion was analyzed without the hydrolysis step, a slight color was obtained while Karathane and Chlorthion gave absorbance readings of 0.650 and 0.250 , respectively. The following insecticides in $100 \mu \mathrm{g}$ quantities gave no interference: aldrin, Aramite, captan, carbophenothion, chlordane, Co-Ral, DDE, DDT, Delnav, demeton, diazinon, dimethoate, Dipterex, Disyston, endosulfan, endrin, Eradex, ethion, Genite, heptachlor, Kelthane, Kepone, lindane, malathion, menazon, methoxychlor, mirex, naled, phorate, Phosdrin, phosphamidon, Phostex, schradan, Sevin, sulfotepp, Sulphenone, TDE, tetradifon, toxaphene, V-C 13 Nemacide, and Zectran.

\section{References}

(1) Averell, P. R., and Norris, M. V., Anal. Chem., 20, 753 (1948).

(2) Kolbezen, M. J., and Barkley, J. H., J. Agr. Food Chem., 2, 1278 (1954).

(3) Young, H. Y., ibid., 8, 213 (1960).

(4) Rosenthal, I., Gordon, C. F., Stanley, E. L., and Perlman, M. H., ibid., 5, 914 (1957).

(5) Niagara Chemical Division Method No. $\mathrm{R}-447 \mathrm{P}-2$.

(6) Chemagro Research Report No. 3382.

(7) Meagher, W. R., Adams, J. M., Anderson, C. R., and MacDougall, D., J. Agr. Food Chem., 8, 4 (1960).

(8) Van Middelem, C. H., Waites, R. E., and Wilson, J. W., ibid., 11, 56 (1963).

(9) Official Methods of Analysis, 9th Ed., Association of Official Agricultural Chemists, Washington, D.C., 1960, sec. 24.132.

Reprinted from the Journal of the Association of Official Agricultural Chemists, Vol. 46, December 1963. 